\title{
Potential Design of Photovoltaics-Pumped Hydro Storage System at Ex-Paser Mine Holes in East Kalimantan
}

\author{
Ilham Muhammad $^{1}$, Thabed Tholib Baladraf ${ }^{2}$ \\ hanifsyahdansidiq2@gmail.com ${ }^{1}$, thabedtholib2001@gmail.com ${ }^{2}$ \\ Geological Engineering Diponegoro University, geologi@ft.undip.ac.id ${ }^{1}$, Agricultural Industsry \\ University of Jember, contact.tip@ agritech.id ${ }^{2}$
}

\begin{abstract}
East Kalimantan has potential for solar radiation of $4,453 \mathrm{kWh} / \mathrm{m}^{2} /$ day which can be used to generate electricity using photovoltaics(PV). This utilization has challenges due to intermittent. East Kalimantan has a Paser Mine covering an area of $1,045,060.20 \mathrm{~m}^{2}$ and $2,566,678.20 \mathrm{~m}^{2}$ which can be intermittency solution used a Pumped Hydro Storage(PHS). This literature review aims to determine the potential design Photovoltaic-Pumped Hydro Storage based on configuration of the mine pit along with charge-discharge of the PHS, capacity of PV, and savings carbon emissions. The writing method uses Engineering Subject Headings include;Carbon Emision, Paser Mine, Photovoltaics, Pumped Hydro Storage, Renewable Energy thus obtaining 30 journals. It was found that the proposed system is capable of supplying electricity with a power of 68.034 MW for 5 hours/day. The system has 451,433 solar panels with a capacity of $115,508 \mathrm{MW}$ on area of $731,321,737 \mathrm{~m}^{2}$. The carbon emission saved reaches $90.991 \% /$ day.
\end{abstract}

Keywords: Carbon Emision, Paser Mine, Photovoltaics, Pumped Hydro Storage,Renewable Energy.

\section{Introduction}

The capital city of Indonesia will be moved to North Paser Regency and Kutai Kertanegara Regency, East Kalimantan [1]. In order for the plan to be realized properly, an indepth study of the infrastructure of the new capital city is needed. One of these infrastructures is electrical energy infrastructure. Since the relocation of the capital city is targeted for completion in 2045, it is necessary to develop electricity infrastructure within 25 years to increase the supply of electricity by $1,175 \mathrm{MW}$ to the two districts [2].

The new capital concept proposed by the government is a smart and green city [3]. This means that the fulfillment of energy for the new capital must be carried out by considering environmental factors. The fulfillment of environmentally friendly energy can be done by using renewable energy-based power plants. In addition to fulfilling this concept, the generation of renewable energy-based electrical energy is also in line with other Indonesian government targets in the form of a national new and renewable energy mix of at least $31 \%$ by 2050 [4].

The development of renewable energy-based power plants must be adjusted to the local energy potential in a region. One of the renewable energy potentials in East Kalimantan is 
solar energy. Solar energy in East Kalimantan reaches 4,629 kWh/m ${ }^{2}$ [5]. With this potential, it is possible to build a photovoltaics (PV) system in East Kalimantan. However, the supply of electrical energy from solar energy can cause new problems, namely the electrical grid system becomes unstable [6]. This is due to the intermittent nature of solar energy. The intermittent nature is indicated by the very varied output of the PV system due to the changing intensity of sunlight.

To overcome this problem, an energy storage system is needed. In practice, there are various types of energy storage systems. One type of energy storage system is Pumped Hydro Storage (PHS). PHS is an energy storage system that is suitable for storing large amounts of energy for a long time. This is due to the low PHS self-discharge and long service life [6]. Unlike batteries which store energy in the form of chemical energy, PHS stores energy mechanically. PHS uses excess energy to pump water to higher ground and drain it back when needed. This PHS system is suitable to be used as an energy storage system for the new capital if a large-scale PV system is to be built to meet its electricity needs.

The challenge in using PHS as energy storage is the preparation of a special location. PHS has a low energy density so it requires a large volume of water reservoir [6]. In addition, PHS requires a place that can store water with a sufficient level (head) difference [6]. In East Kalimantan, there are ex-open pit mines that can be used as water reservoirs.

East Kalimantan has 632 ex-open pit mining pits that have been left unattended [7]. However, not all ex-mining pits can be used as PHS. Holes that can be utilized are holes that meet the criteria described in the previous paragraph. A pair of holes that meet these criteria are the holes studied by Mar'atus Sholichah Zuliana in his thesis "Analysis of Potential Utilization of Ex-Coal Mining Land as a Pumped Hydro Storage Electrical Energy Storage in the Paser Region, East Kalimantan". The volume of a pair of ex-mining holes studied, hereinafter referred to as Ex-Mining Hole $\mathrm{X}$, is $32,552,281 \mathrm{~m}^{3}$ and $191,665,924 \mathrm{~m}^{3}$ with a maximum water level difference of $150 \mathrm{~m}$ [8]. The ex-mining pit also has a surface area of $1,045,060,2 \mathrm{~m} 2$ and $2,566,678.2 \mathrm{~m}^{2}$, so it has the potential to be used as a place to place solar panels with a floating PV concept.

The research conducted by Mar'atus Sholichah Zuliana focuses on analyzing the potential utilization of ex-mining pits as PHS, so that the PHS design does not include consideration of the profile of sunlight availability, load requirement profile, and PV systems that supply the PHS system. Therefore, in writing this scientific paper, the design of a PV system with a PHS energy storage system at the Ex-Mining Hole $X$ is carried out whose operating scenario is adjusted to the profile of the availability of sunlight and the profile of load requirements.

\section{Literature Review}

\subsection{Discharge Process}

The discharge process is the process of generating electricity by PHS. When the discharge process takes place, water is flowed from the upper reservoir to the lower reservoir through a pipeline. The water will pass through the turbine and drive the turbine blades. The turbine rotates and is connected to a generator so that it can produce electricity. System discharge efficiency is systematically written as follows [9].

$$
\eta d=\eta T \times \eta G \times \eta P
$$

For the calculation of the electrical power of the system, it is obtained using equation (2) as follows 


$$
P=\rho x \eta d x g \times Q \times h
$$

For the calculation of the system's discharge and energy, using equations (3) and (4)

$$
\begin{aligned}
& Q=\frac{V}{t} \\
& E=\int P(t) d t
\end{aligned}
$$

\subsection{Charge Process}

The charge process is carried out when there is a surplus of energy where the energy produced is more than the energy needed. This charge process is carried out by pumping water into the upper reservoir. To maintain the sustainability of the PHS system, the volume of water pumped back up must be equal to the volume of water that has been lowered during the discharge process [10]

Calculation of pump power can be done with the following equation

$$
\text { Ppompa }=\frac{\rho \times g \times Q \times h}{\eta c}
$$

\subsection{Turbine}

There are various types of water turbines, such as Pelton, Francis, and Kaplan turbines. These turbines have their respective work areas so that the selection of the type of turbine needs to be adjusted to the existing conditions. Pelton turbines are used to generate hydroelectric power with high head and low discharge. Kaplan turbines work well when the water has a low head and high flowrate. Meanwhile, the francis turbine is in between, i.e. it works well at medium head and discharge. The specific speed of the turbine is defined as follows [11]

$$
N s p T=\frac{N \sqrt{P / \rho}}{(g H E)^{5 / 4}}
$$

\subsection{Pump}

Like turbines, pumps also consist of several types that work optimally in a certain working range. The parameter that becomes the reference for selecting the pump is the specific speed of the pump. Specific speed is defined as follows [12]

$$
N s p T=\frac{N \sqrt{Q}}{(g H E)^{5 / 4}}
$$

\section{Research Methods}

\subsection{Method}

This type of research is a literature review compiled using secondary data in the form of sources obtained based on the listed bibliography.

\subsection{Subject of This Research}

The subject of this research is obtain the data from journals in the form of research articles, guidelines, or electronic books such as from Scopus, Elsevier, Google Scholar, and 
other technical and energy journals as many as 15 sources. The keywords used include Carbon Emission, Paser Mine, Photovoltaics, Pumped Hydro Storage, Renewable Energy.

\subsection{Instrument}

The research instruments used were Google Search Engine to search for data, Microsoft Word as a word processing application, MEdeley for processing bibliography and Corel Draw X7 as a graphic design application to create designs.

\subsection{Data Analysis}

The analytical method used is a systematic literature review, namely an analytical method that identifies, examines, evaluates, and systematically develops existing research with a specific focus on appropriate and relevant topics. The analytical methods carried out are (1) determining the configuration of the ex-mining pit; (2) calculate the volume of water operated; (3) calculating the energy potential in East Kalimantan; (4) determine the configuration of PHS discharge and charge processes; (5) determine the configuration of the photovoltaics system; (6) selecting the main components of PHS in the form of pumps and turbines; (7) calculating PHS discharge and charge power; (8) calculate the capacity, number of photovoltaics modules, and land area required by the photovoltaics system; and (9) calculate carbon emission savings.

\section{Results and Discussion}

\subsection{Mine Pit Configuration}

In this study, the PHS system was built at Hole Former Mine X located in East Kalimantan. Data related to the volume and contours of ex-mining pits were taken from a thesis research conducted by Mar'atus Sholichah Zuliana. The research has conducted an analysis of the potential for PHS. However, the potential analysis has not considered the load requirements and the availability of solar energy. In addition, the study also did not design a PV system.

The volume of water operated daily in this study was $1 / 7$ of the volume of water operated in the study of Mar'atus Sholichah Zuliana $\left(9,437,167.98 \mathrm{~m}^{3}\right)$ [8]. This takes into account the existence of energy reserves stored in the PHS system if there is no energy supply from the PV system for a maximum of one week. Thus, the volume of water that is operated daily is $1,348,166.854 \mathrm{~m}^{3}$.

\subsection{Discharge Process Configuration}

In this study, the PV-PHS system is designed to distribute electrical energy when a peak load occurs. The daily electricity load profile for the new capital is assumed to be the same as the Indonesian daily electricity load profile. Thus, the discharge of photovoltaics-PHS was carried out for 5 hours from 7.00 to d. 22.00 WITA.

The water discharge that flows from the upper reservoir to the lower reservoir during the discharge process can be calculated using Equation (3) where the discharge time is 5 hours and the volume of water operated is $1,348,166.854 \mathrm{~m}^{3}$. Thus, the average discharge value is $74,898 \mathrm{~m}^{3} / \mathrm{s}$. The average discharge head is assumed to be equal to the median value between the maximum head (when the water level in the upper reservoir is $0 \mathrm{~m}$ and the water level in 
the lower reservoir is $-113.6 \mathrm{~m}$ ) and the minimum head (when the water level in the upper reservoir is $-9.515 \mathrm{~m}$ and the water level in the lower reservoir is $-105.897 \mathrm{~m}$ ) [8].

\subsection{Charge Process Configuration}

Through Equation (3) and the working volume in section 4.2, it is known that the water discharge that is increased during the charge process is $80.895 \mathrm{~m}^{3} / \mathrm{s}$. The character of the water and reservoir is the same as the discharge process so that the density, gravitational acceleration, and head values are the same as during the discharge process.

\subsection{Pump Selection and Calculation of Power and Energy Charge}

The selection of pump type is based on the graph of specific speed, geometry, and pump efficiency in Figure 1 and Figure 2.

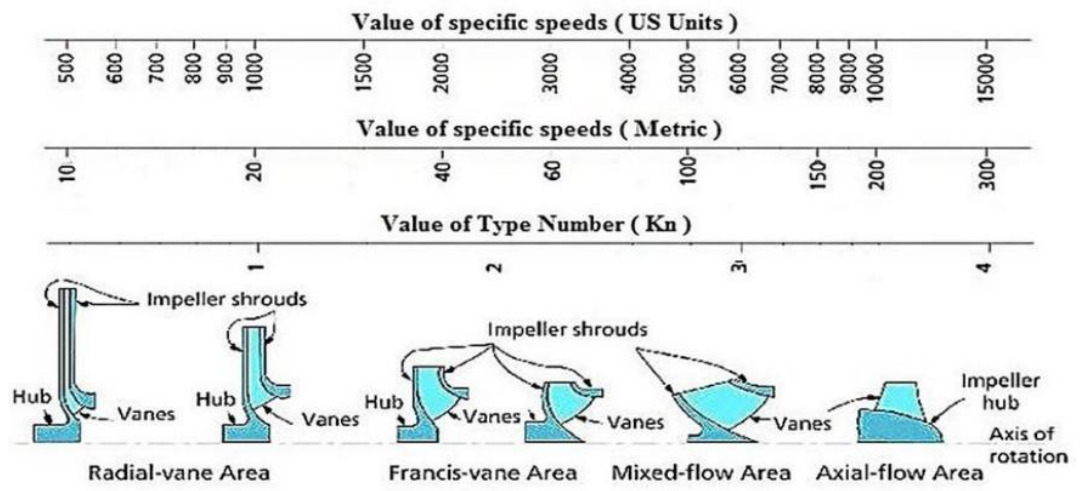

Fig 1. Relationship between pump specific speed and pump geometry [13]
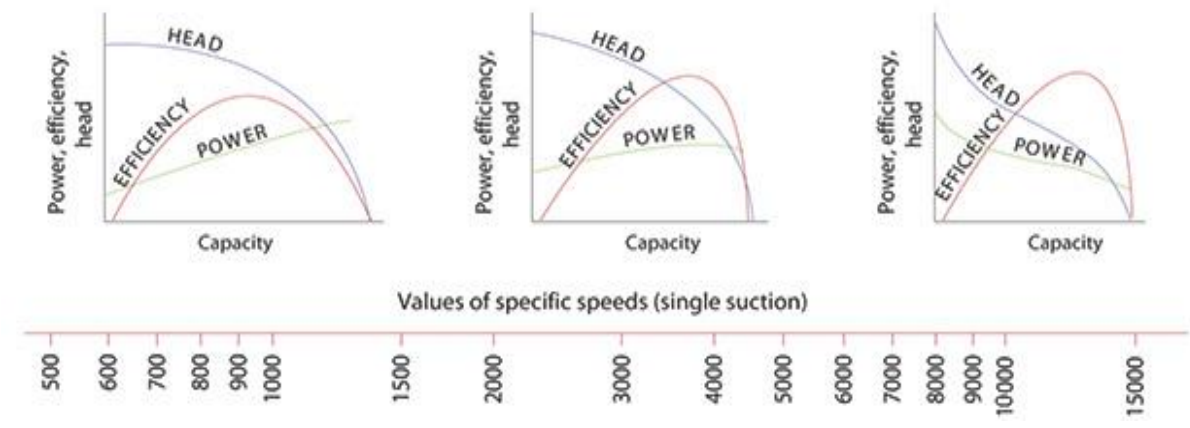

Fig 2.Specific speed and pump performance curves [13]

However, since Equation (2.10) shows an implicit equation between specific speed and pump efficiency, an iterative calculation process is needed to determine the type of pump and power. required. In the calculation, it is assumed that the pipe diameter, pipe efficiency, and motor efficiency are 6 meters, $96.50 \%$, and $85.00 \%$ [11]. The alternator poles are assumed to be 16 pieces with an output power frequency of $50 \mathrm{~Hz}$. Through all of equation, we get a PHS system with a charge system character shown in Table 4.4. Based on Figure 1, the suitable type of pump is centrifugal. 


\subsection{Potential of Solar Energy in East Kalimantan}

In general, the value of the intensity of solar radiation in West Kalimantan ranges from 165-219 Watt $/ \mathrm{m}^{2}$. The difference in solar radiation values at 7 (seven) West Kalimantan BMKG stations is not too significant because the station positions are located between 20LS to 20LU and the station elevations are almost the same [14]. The maximum intensity of solar radiation occurs in July and August, this is because July and August are the peak periods of the dry season so that solar heating to the earth's surface is most optimal. The minimum intensity of solar radiation occurs in December and January because this month is the peak of the rainy season where the growth of convective clouds is very much so that it blocks solar radiation to the earth's surface.

In utilizing the potential of solar energy for power generation, the unit is usually $\mathrm{kWh} / \mathrm{m}^{2}$ day, so that the value of solar radiation in West Kalimantan is between $3.96-5.25$ $\mathrm{kWh} / \mathrm{m}^{2}$ day. This value is quite high, especially in Mempawah and Ketapang, considering the average solar radiation in Indonesia is $4.8 \mathrm{kWh} / \mathrm{m}^{2}$ day. This energy, when used to turn on 20 watt lamps, is able to turn on between 19 - 26 lamps assuming 10 hours/day usage and using a $1 \mathrm{~m}^{2}$ solar panel [14].

\subsection{PV System Configuration}

The solar panel selected in this system is the Sunmodule Plus SWA 315 Mono made by Solar World Americas Incorporate. The module was chosen because it has high efficiency. The specifications of this solar panel when tested at a temperature of $25^{\circ} \mathrm{C}$ are as follows [15].

Table 1.Specifications of the solar panels used

\begin{tabular}{lll}
\hline Paramater & Quantity & Unit \\
\hline Material & Mono-c-Si & - \\
Number of Cells & 60 & - \\
Module Width & 1 & $\mathrm{~m}$ \\
Module length & 1,62 & $\mathrm{~m}$ \\
Module efficiency & $19,628 \%$ & - \\
Output power & 317,968 & $\mathrm{~W}$ \\
Temperature & & ${ }^{\circ} \mathrm{C}^{-1}$ \\
coefficient & $-0,406 \%$ & \\
\hline
\end{tabular}

\subsection{Calculation of the Number of Solar Panels Needed}

The PV system must be able to supply the pump power and energy described in section 4.6. With a pump power of $115.508 \mathrm{MW}$, the output power of each module is 317.968 $\mathrm{W}$, and the efficiency due to losses is $80.470 \%$, the number of solar panels needed is 451,433 units. Based on the dimensions of the solar panels in Table 1, the number of solar panels requires an area of 731,321,737 $\mathrm{m}^{2}$. With an upper reservoir surface area of 1,045,060,200 $\mathrm{m}^{2}$ and a lower reservoir of 2,566,678,200 $\mathrm{m}^{2}$, the required land area for the PV system is smaller than the reservoir surface area, so that the PV system can be placed on the surface of the 
reservoir with a floating PV concept. The illustration of the proposed system is shown in Figure 3 . The figure is only an illustration that does not take into account the scale.

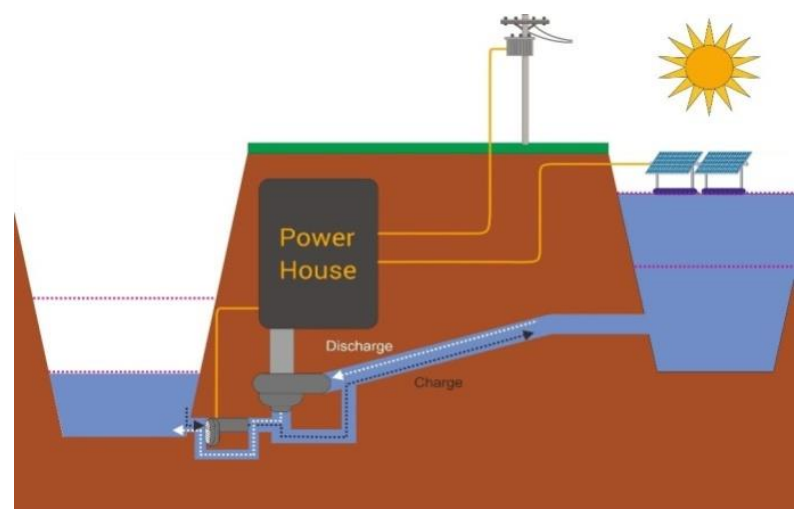

Fig 3. Illustration of the proposed PV-PHS system.

\section{Conclusions}

The proposed PHS design for Ex-Mining Hole X can match the availability of energy supply and load requirements. PHS can store electricity from a PV system with a power of $115,508 \mathrm{MW}$ for 4,629 hours with an efficiency of $73.823 \%$. PHS can supply electricity to the prospective new capital with a power of 68.034 MW during peak loads (5 hours) with an efficiency of $86.175 \%$. The PV system has a capacity of $115,508 \mathrm{MW}$ with 451,433 solar panels occupying an area of $731,321,737 \mathrm{~m} 2$. Because the surface area of the PV system is smaller than the surface area of the PHS reservoir, the PV system can occupy the surface of the PHS reservoir as floating PV.

\section{Acknowledgements}

This article could not have been realized without the help of the Geological Engineering of Diponegoro University lecturer and Agricultural Industsry University of Jember lecturer, so we thank you. And to all those who have helped the smoothness of conducting research, thank you

\section{References}

[1] Direktur Jenderal Ketenagalistrikan. Isu dan capaian subsektor ketenagalistrikan. Jakarta: Direktorat Jenderal Ketenagalistrikan; 2019.

[2] Nurrohim A. Pembangkit listrik tenaga hibrid sebagai solusi kelistrikan di daerah terpencil. Jurnal Sains dan Teknologi Indonesia. 2012; 14(2): 96-103.

[3] Dixon SL, Hall CA. Fluid mechanics and thermodynamics of turbumachinery. Seventh edition.Waltham: Elsevier Inc; 2014.

[4] PT. PLN (Persero). Electric power supply business plan (2019-2028) . Jakarta: PT. PLN; 2019.

[5] Handayani NA, Ariyanti D. Potency of solar energy applications in Indonesia.. International Journal Renewable Energy Development. 2012; 1(2): 33-38.

[6] Fuchs G, Lunz B, Leuthold M, Sauer D U. Technology overview on electricity storage - 
overview on the potential and on the deployment perpectives of electric storage technologies. Germany: RWTH Aachen University; 2012.

[7] Rande S. Analisis kesesuaian lahan bekas tambang batubara pada Pt Asia Multi Invesama di Kabupaten Tebo Provinsi Jambi. Promine Journal. 2016; 4(2): 17-27.

[8] Herdiansyah H, Utami MU, Haryanto, JT. Sustainability of post-mining land use and ecotourism. Jurnal Perspektif Pembiayaan dan Pembangunan Daerah. 2018; 6(2): 167-180.

[9] Arroyo FR, Miguel LJ. The role of renewable energies for the sustainable energy governance and environmental policies for the mitigation of climate change in ecuador. Energies. 2020; 13(15): 1-18.

[10] Hosseinalizadeh R, Shakouri H, Amalnick G, Taghipour P. Economic sizing of a hybrid (PVWT-FC) renewable energy system (HRES) for stand-alone usages by an optimizationsimulation model: Case study of Iran. Renewable Sustainable Energy Revolution. 2016; 54(1): 139-150.

[11] Tan X, Engeda A. Performance of centrifugal pumps running in reverse as turbine: Part II systematic specific speed and specific diameter based performance prediction. Renewable Energy. 2016; 99(1): 188-197.

[12] Jafarzadeh B, Hajari A, Alishahi MM, Akbari MH. The flow simulation of a low-specific-speed high-speed centrifugal pump. Applied Math. Model. 2011; 35(1) 242-249.

[13] Zhou X, Zhang Y, Ji Z, Chen L. Hydraulic design and performance analysis of low specific speed centrifugal pump. 26 th IAHR Symposium on Hydraulic Machinery and Systems; 19-23 August 2012; Beijing. IOP Conference Series: Earth and Environmental Science 15; 2012. p. 1 8 .

[14] Islammiyati I, Azwar A, Sutikno S. Analisis potensi energi matahari menggunakan data lama penyinaran matahari (LPM) Kota Pontianak. Prisma Fisika. 2019; 7(3): 238-245

[15] Blair N, Orio N, Freeman J, Gilman P, Janzou S, Neises T, Wagner M. System Advisor Model (SAM). United States: National Renewable Energy Laboratory; 2017. 